\title{
A COMPARATIVE ANALYSIS OF INSTITUTIONAL FRAMEWORKS FOR NATIONAL PARKS IN THE COUNTRIES OF THE FORMER YUGOSLAVIA
}

DOI: http://dx.doi.org/10.18509/GBP.2018.23

UDC: 502.13(497.1-751.2)

\author{
Milan Lalić \\ Faculty of Science, Department of Geography, Tourism and Hotel Management, \\ University of Novi Sad, Serbia
}

\begin{abstract}
National parks have a special significance among numerous forms of protected natural and social heritage. This is not only the result of their number and size, but also of multiple significance for science, culture, education, recreation, tourism and the protection of natural ecosystems. Compared to developed countries, nature protection in the former Yugoslavia started quite late, which is no wonder considering the events in the world at the moment and the current circumstances, although the importance of the regulation of nature protection is recognized early. The first national parks in the former joint state were declared in 1948 (Macedonia) and 1949 (Croatia). In the former Yugoslavia there were 22 national parks, and the successor states in its territory in the next two decades declared three more national parks.

National parks are protected by a special regime provided for by special legislation. Managing National Parks is a complex process that includes biological, social, legal, economic and many other components. The development of national parks is not possible without management plans. The aim of this paper is to analyze the institutional frameworks and management capacities, as well as the potentials of national parks in the countries of the former Yugoslavia. The basic conclusion is that, with evident differences between individual countries, in most countries nature protection is well organized, but due to the lack of harmonization of legislation, the situation in the functioning of national parks is far from satisfactory. There is a need for upgrading management plans. National parks are faced with a lack of funds to undertake protection and other activities, so it is not possible to adequately use their abundant potentials and values.
\end{abstract}

Keywords: national parks, institution, institutional framework, management, law

\section{INTRODUCTION}

National parks (NPs) have a special significance among numerous forms of protected natural and social heritage. This is not only because of their number and size, but also due to their multiple significance for science, culture, education, upbringing, recreation, tourism and protection of natural ecosystems. NPs are areas of outstanding beauty, where ecosystems are not polluted by human activity. With their specific morphological characteristics, they are national treasures for present and future generations [6].

Their protected status ensures that these areas are designated for overall sustainable development, which is considered to be a priority management objective.

The main focus of this paper are NPs as the most complex categories of protected areas in the territories of the former Yugoslavia. 
What is meant by the name former Yugoslavia is the territory of the country which used to be The Socialist Federal Republic of Yugoslavia (SFRY) until June 25th 1991, comprising six republics which were part of the Federation: Bosnia and Herzegovina, Montenegro, Croatia, Macedonia, Serbia (including the provinces Kosovo and Vojvodina) and Slovenia. SFRY practically ceased to exist on June $25^{\text {th }} 1991$, when Slovenia and Croatia declared their independence. By April 1992, two republics Macedonia and Bosnia and Herzegovina also adopted their declarations of independence, leaving behind only Serbia and Montenegro in the Federation. These two republics declared the Federal Republic of Yugoslavia (FRY) on April 27th 1992. The Federal Republic of Yugoslavia (FRY) was reorganized and renamed into the State Union of Serbia and Montenegro in 2003, which formally and physically ceased to exist after the declaration of independence by Montenegro on June $3^{\text {rd }} 2006$ and by Serbia on June $5^{\text {th }}$ 2006 [15].

Of all the countries formed on the territory of the former Yugoslavia, two are members of the European Union (EU): Slovenia (since 2004) and Croatia (since 2013), three have the status of candidate countries: Macedonia (since 2005), Montenegro (since 2010) and Serbia (since 2012), whereas Bosnia and Herzegovina submitted the membership application (2016). Montenegro started negotiations in 2012 and Serbia in 2014.

\section{METHOD}

Methodological approach is the application of analytical, synthetical and comparative analysis methods. Analytical method is used to identify and interpret collected data and facts about protected natural areas, namely NPs in the countries of the former Yugoslavia (the analyzed area). In this way, through the comparison with the elements of generalization methodology, we will analyze the historic context, development and conditions under which the processes of establishing and managing protected areas were developed globally and in the analyzed area.

The obtained analytical data are synthesized and based on the synthetical overview of the phenomena and processes, general conclusions are drawn about the status and the relationship between the institutions and organizational management in the protected natural areas.

Comparative analysis method and its methodological foundations apply the observation of practical elements, targeting the use of protected natural areas and the application of management planning in NPs [5]. In this methodological framework, planning and other organizational solutions will be compared in national parks in the countries of the analyzed area, especially in view of their different status regarding the EU, which is connected with the dynamics of adjusting legal regulations with the EU regulations depending on the country's status (member, candidate member, opening and closing individual chapters).

\section{NATIONAL PARKS}

The establishment of NPs began in the $19^{\text {th }}$ century, after Yellowstone National Park was established in the U.S.A. In 1916, NP Service was formed within the park, with the purpose to "conserve the scenery, all the natural and historic objects in the area and the wild life therein, and to provide for future generations to visit the area" [1]. The Park was 
put under the supervision of the federal authorities, and its dedication, based on the concept of a public estate, open for the benefit and enjoyment of everyone, presented a foundation stone for all future national park dedications around the world. After the dedication of the first NP, the concept was adopted outside the U.S.A. as well. The oldest NPs in Europe - Sarek and Stora Sjöfallet were established in 1909 in Lapland in northern Sweden, in the area of the most representative parts of subarctic tundra. This was followed by the establishment of Swiss NP in the part of Swiss Alps along the glacial valley Engadin in 1914 [1].

In order to improve the understanding and awareness about the significance of protected areas, International Union for Conservation of Nature (IUCN) developed a unique system of classifying protected natural heritage, distinguishing six categories identified by the primary management objectives in these areas [3]. A primary characteristic of this classification is the fact that it is based on ecology. A national park as category II is defined as "a protected area primary established for ecosystem conservation and recreation".

Although it has been almost a century and a half since the dedication of the first NP in the world, there are still significant differences in the size of the territory that is protected, the way of management planning and financing, as well as the regime of protection in different countries. The term "national park" is not exclusively reserved for the category II and, in many countries, it often refers to protected areas regardless of the management status in the natural heritage site [4].

In terms of history, the significance of the nature protection regulations was early recognized in the territory of the former Yugoslavia (The Valley of Triglav Lakes in 1924, the area of Plitvice Lakes in 1928), also after the First World War in 1918, the Ministry of Forests and Mines was established by the Decree of the Kingdom of Serbs, Croats and Slovenes, followed by the Order of Protecting and Preserving Objects of Historic, Scientific, Artistic Values, Natural Beauties and Rarities in 1930, which were declared as such in order to conserve the most important areas of preserved nature, and this was followed by the Act on NPs. However, there were not any officially declared NPs until the end of the Second World War [1].

Table l. Overview of national parks in the countries of the former Yugoslavia (2010)

\begin{tabular}{|l|r|r|c|}
\hline \multicolumn{1}{|c|}{ Country } & number of national parks & area of protected areas & \multicolumn{1}{c|}{$\%$} \\
\hline Bosnia and Herzegovina & 3 & 408.20 & 0.8 \\
\hline Croatia & 8 & 979.63 & 1.73 \\
\hline Macedonia & 3 & $1,074.37$ & 4.18 \\
\hline Montenegro & 5 & $1,075.00$ & 7.78 \\
\hline Slovenia & 1 & 839.82 & 4.14 \\
\hline Serbia & 5 & $1,590.10$ & 1.8 \\
\hline Total & 25 & $5,967.12$ & 2.33 \\
\hline
\end{tabular}

This field was regulated on the level of the republics in the former Yugoslavia. By the Decision of the Sobranie of the People's Republic of Macedonia, the first NP was declared not only in the territory of Macedonia but also in Yugoslavia, whose constituent republic was Macedonia. The Pelister NP was established on November 30th 1948. 
During 1949, Mavrovo NP was also declared [8]. In 1949, there was the Law on Declaration of Plitvice Lakes NP and Paklenica NP, the first modern NPs in the territory of Croatia. The first institutionalized forms of protected natural areas in Montenegro can be found in 1952, when the Law on Declaration of Forest Areas of Lovćen, Biogradska Gora and Durmitor NPs was adopted on August $5^{\text {th }}$ the same year by the Decree of the Presidium of the Montenegro National Assembly. In Serbia, the first NP was protected only in 1960 , when the status was given to Fruška Gora, which was declared a national excursion site.

Eleven NPs were declared by 1960, and four additional ones in the next twenty years. In the territory of Yugoslavia, 22 national parks were declared by 1992. After this, two more NPs were declared (Northern Velebit NP in Croatia in 1999, Una NP in B\&H in 2008, and Prokletije NP in Montenegro in 2009).

The largest number of NPs can be found in Croatia, and Slovenia declared only one NP. The largest surface area under NPs is in Serbia. Out of the country total area, the largest area under NPs is in Montenegro (7.78\%), and the smallest in B\&H $(0.80 \%)$.

Note: In the territory of Kosovo, Prokletije NP was declared in 2012, and in July 2017, Drina NP was declared in the territory of the Republic of Srpska $(B \& H)$.

\section{RESULTS AND DISCUSSION}

If you compare the existing situation in the structure, organization and management in protected areas in the countries of the former Yugoslavia, there are a lot of similarities, but also some obvious differences. In some countries, the establishment and operation of the managing institution is regulated by special legal acts, very often by the Acts declaring the protected area.

A starting point for legal regulations in the area of environmental protection and nature conservation can be found in the Constitutions of each of the countries in the analyzed area, referring to the fundamental freedom and rights of humans and citizens. In the five countries of the analyzed area, the state is the founder of NPs, except for B\&H where the founders are entities, but this fact does not have an influence on the necessary level of organization and management, because international organizations for nature conservation, without exception, measure efficiency only by the concept and the quality of institutional management, and the quality of management is evaluated by the quality of legal framework and documents, as well through the actual functioning of the institutions responsible for the management of the protected area. It should be emphasized that the adoption of IUCN general guidelines for the management of protected areas makes institutional protection obligatory, which means that it is necessary to establish a management body and provide for the preparation and adoption of primary documents for management [2].

What is common for all the countries is that NPs are managed by public enterprises. Preservation, improvement, sustainable use, organization and interpretation of natural and other values in the NPs areas, are conducted according to the management plan, which is adopted for a ten-year period, with the content and the activities defined by legal acts for nature conservation planning. The management plan is implemented through the annual management program for NPs.

In Serbia, NPs are managed by Public Enterprises (PE) - the total of five PE, separately organized for each of the NPs. The founding rights belong to the government. The management program is agreed upon with the Ministry of Environmental Protection. For 
the NP areas, a spatial plan is adopted for special-purpose areas, which defines protection regimes of I, II and III degree, in accordance with the Law on NPs. The Expert Council of NPs is an expert and consulting body monitoring and analyzing programs and projects in the field of nature conservation and the sustainable use of natural resources. The president and the members of the Expert Council are appointed by the Ministry. The compliance with the legal provisions is monitored by the Ministry. The inspection monitoring is done by the Ministry via inspectors in charge of the environmental issues. Serbia has implemented a series of measures to comply with legal and institutional framework with the EU standards since 2009 [10].

In Croatia, this area is regulated by the Law on Nature Protection, the Law on Institutions and the Constitution. NPs are declared by the Law adopted by the Croatian Parliament [2]. Protected areas are registered in the Register of Protected Areas, kept by the Ministry of Environment Protection and Energy. Protected areas are managed by public institutions. Public institutions for managing NPs are established by the Government Decree of the Republic of Croatia. A public institution that manages the protected area is led by the governing council with up to five members. The President and the members of the governing council, as well as the general manager of the public institution managing the NP, are all appointed and dismissed by the Minister. The organization of the area, its use, organization and protection in the NP are all regulated by the special-purpose area spatial plan, based on the expert study conducted by the Institute. The executive compliance monitoring of the applicable law is conducted by the Ministry. The inspection compliance monitoring of this Law and the regulations defined by the Law is done by government inspection officers of the Ministry of Environment Protection [2], [14].

In Slovenia, in compliance with the Law on Triglav National Park [13], the Public Institution Triglav National Park was established by the Republic of Slovenia, and the founding rights and obligations belong to the Government of the Republic of Slovenia. The Governing Council adopts a draft management plan and sends it to the Ministry which presents it to the Government which adopts it by a decree. In compliance with the adopted management plan, the Public Institution adopts its annual agenda for financial evaluation. The bodies of the Public Institution are council, expert council and director. The Council is the highest governing body of the Park and gathers representatives from the founders of the NP, local community, employees, interested public institutions. Public participation in managing the NP is provided for and conducted through the stakeholder forum of the Triglav National Park [13].

The responsibilities in the area of nature protection in Bosnia and Herzegovina (B\&H) are regulated at the entity level (the Republic of Srpska and the Federation B\&H), as well as for the Brčko District. Fundamental legal acts which are essential for nature conservation, especially the protected area category and the protective actions, include the Law on Nature Protection of the Federation B\&H for the Federation B\&H, the Law on Nature Protection of the Republic of Srpska for the Republic of Srpska and the Law on Nature Protection of the Brčko District, B\&H for the Brčko District [16].

A part of the responsibilities in the field of nature protection is regulated at the federal level and refers to the compliance of $\mathrm{B} \& \mathrm{H}$ with international obligations (monitoring and coordination of preparations for closing and implementation of international agreements, project coordination in cooperation with international organizations, programs and funds, coordination of cooperation with the institutions in $\mathrm{B} \& \mathrm{H}$, entities and the Brčko District. Environmental protection issues that require harmonized approach of the entities are dealt with by the Inter-Entity Environmental Protection Body. This refers to, inter alia, issues 
of international agreement and programs, participating in cooperation with international organizations, the coordination of the implementation and adoption of legal acts, etc [16]. In the Republic of Srpska pursuant to the Law on NPs, public institution is established by the Republic, in accordance with the law governing the public services system. Public institution bodies are the governing board and the director, appointed and dismissed by the Government of the Republic of Srpska, upon the proposal of the Ministry for Environmental Protection, after the conducted public bid [11], [16].

In the Federation B\&H, Public Institution Una National Park was established to manage the NP. The founding rights in the Public Enterprise are exercised by the Federation Government on behalf of the Federation of Bosnia and Herzegovina. The Public Enterprise performs its activity as a public activity. The Government of the Federation $\mathrm{B} \& \mathrm{H}$ has determined that the natural values, real estate and objects which serve to nature protection and the management of the NP, and which are state-owned in the NP area, are to be managed by the Public Enterprise. Relevant inspection authorities are performing inspection monitoring of certain provisions of the Law on Una NP, then regulations and conditions issued pursuant to this Law. In addition to inspectors, compliance monitoring of certain provisions is performed by the supervisors of the Public Enterprise, who are organized as a supervision service for nature protection within the Public Enterprise. In implementing direct supervision of the compliance with the Law, certain public services from the forestry and hunting departments are required to cooperate in the area of the NP where they conduct permitted activities [12].

In Montenegro, in accordance with the provisions of the Law on NPs, the management body of the NP defines the role of the Public Enterprise for NP. The Assembly of Montenegro has the rights and obligations of the Public Enterprise founders. Legal norms define the supervision of the company operations, as well as the prescribed protection measures and the financing ways of national parks. There is a special provision for the content of annual management programs of the NPs, which are drafted by the Public Enterprise for NP pursuant to this Law, and verified by the responsible Ministry [5].

In Macedonia, the management plan for protected areas is regulated by the Law on Nature Protection. According to this Law, the management, supervision and protection of the NP is performed by the Public Institution National Park, established by the Government of the Republic of Macedonia. Within this legal framework, the Government established three public institutions for the management of the NPs in 2016. The public institution of an individual NP is the managing authority, adopting the management plan and annual programs that determine special measures and activities for nature protection upon prior consent from the state administration body in charge of the field of nature protection. Public Institution bodies of the NP are: the governing board, executive body, expert collegial body and the board for material and financial control. The Governing Board consists of five members (two representatives from the Ministry, a representative of the municipality in which the NP is located and two representatives of the expert body). The board adopts the NP Statute, the park management plan, monitors its execution, determines the level of compensation, the financial plan and adopts the annual financial report and elects the president from the members of the board [9].

The comparison of the institutional solutions in the countries of the former Yugoslavia shows that there are efforts to organize the protected areas in the best way possible, especially regarding the NPs, either through a unique Law on National Parks or a Law for each individual park, which clearly determines their interest in nature protection. A unique enterprise as a model for managing national parks could be a good model (e.g. 
Serbia, B\&H, Montenegro). However, the results in the implementation of such solutions have shown that these protected areas are still behind the protected areas in Croatia. We should certainly mention the Federation B\&H which has only recently established its first national park, the Una NP, where they used all the experience and knowledge from the experts in Croatia. The example of one national park in Slovenia shows that even some countries in the European Union have certain weakness in their solutions: hunting is permitted in the Triglav NP, although it is an inappropriate activity in most of the protected areas in the world, as well as giving concessions [2].

The current situation in the functioning of NPs in Macedonia is far from being satisfactory. There is a need for upgrading management plans. NPs in Macedonia are facing the lack of funding and it is extremely difficult to perform protective and other activities without it. Without stronger support from the state budget it is not possible to use rich resources and values of parks. The Government, together with the municipalities and other stakeholders, needs to show support in the protection of the park values and in the use of huge potentials which could contribute to the local development, especially ecotourism [7].

Institutional framework and some solutions in the U.S.A. can be an interesting guideline in for our protected areas, especially when it comes to allowed models of financing and the roles of certain bodies in the realization of the idea [2].

\section{CONCLUSION}

National parks are protected with the special regime which is regulated by separate legal framework. The managing of national parks is a complex process involving biological, social, legal, economic and many other elements. Global experiences should be used more and in better ways, emphasizing the multiple values and functions of national parks with the aim of the best possible benefits.

The main conclusion is that, in addition to obvious differences among individual countries, nature protection is well-organized in most of them, but due to the shortcomings in the harmonization of the legal system, the situation in the functioning of the NPs is far from being satisfactory.

There is a need for upgrading the management plans. National parks are facing the lack of funding for protection and other activities, so it is not possible to adequately use their rich resources and values. It is completely clear that nature protection, despite all the problems and insufficient legal framework, is relatively well-regulated and that these countries are following the trends which became standards in the EU and the world. Considering the status of individual countries in the EU, the difference is in the degree of implementing individual provisions and directives of the EU which refer to the field of nature protection, including NPs.

However, it is obvious that these regulations are not enough in the protection and conservation of nature, but the society as a whole is of utmost importance, i.e. each individual member, whose responsible behavior is a link for the future of nature as a whole, especially because nature protection and environmental care have not reached the deserved level, and without this, the future is rather uncertain for all of us. There are many reasons for this situation, from those referring to the fast development and progress which do not take into account which interventions in nature should be allowed and justified, i.e. developed sustainably, then legal regulations which are not harmonized and are 
overlapping in different fields, as well as the influence of politics and the lack of adequate studies [2].

\section{REFERENCES}

[1] Амиџић, Л. Водич за управљање заштићеним подручјима, Министарство животне средине, рударства и просторног планирања, Факултет за примењену екологију „Футура“, Фондација за еколошке акције Green Limes, Београд, 2011;

[2] Bulat, Ž. Institucionalni okvir zaštite prirode u Republici Hrvatskoj, Pravni vjesnik god. 28, br. 2, pp. 94-111, Zagreb, 2012;

[3] Eagles, P. \& McCool, S. \& Haynes, C. Sustainable Tourism in Protected Areas (Guidelines for Planning and Management). Cambridge: IUCN, Cardiff University, UNEP, WTO, 2002;

[4] Jovičić, D. Turizam i životna sredina, Ton Plus, Beograd, 2010;

[5] Luburić, V. Uvođenje novih upravljačkih mjera u zaštićenim područjima sa ciljem unapređenja modela zaštite prirode u Crnoj Gori - doktorska disertacija, Univerzitet u Novom Sadu, Prirodno-matematički fakultet, Departman za geografiju, turizam i hotelijerstvo, Novi Sad, 2016;

[6] Станковић, С. Национални парк Ђердап - полифункционална туристичка регија, Гласник Српског географског друштва, LXXXIII-1, Београд, 2003;

[7] Šapurić, Z.\& Zenki V. Management plans of the national parks in Macedonia,

International Journal of Ecosystems and Ecology Sciences (IJEES) Vol. 2 (2): 33-38 Plainfield, Illinois, USA, 2012;

[8] Томић, П. \& Ромелић, J. \& Кицошев, С. \& Плавша J. \& Марковић, С. \& Стојановић, В. Туризам и заштита, Природно-математички факултет, Института за географију, Нови Сад, Србија, 2000;

[9] Закон за заштита на природата, Службен весник на Република Македонија број 67/2004;

[10] Закон о националним парковима, Службени гласник РС бр. 84/2015;

[11] Закон о националним парковима, Службени гласник Републике Српске број 75/10, 2010;

[12] Zakon o nacionalnom parku Una, Sl.novine FBiH, br. 44/2008, 2008;

[13] Zakon o Triglavskem narodnem parku, Uradni list RS, št. 52/10, 46/14, 2014;.

[14] Zakon o zaštiti prirode. Narodne novine, broj 80/13, 2013;

[15] http://www.icty.org/bcs/o-mksj/sta-je-bivsa-jugoslavija

[16] http://nasljedje.org 